\title{
THE GENESIS OF THE TEST MOTIVE IN FAIRY TALES REFLECTED IN RIDDLES
}

\author{
Munis Juraeva \\ Senior Research Fellow, Institute Of Uzbek Language, Literature And Folklore, Uzbekistan \\ Jamila Askarova
}

Senior Research Fellow, Institute Of Uzbek Language, Literature And Folklore, Uzbekistan

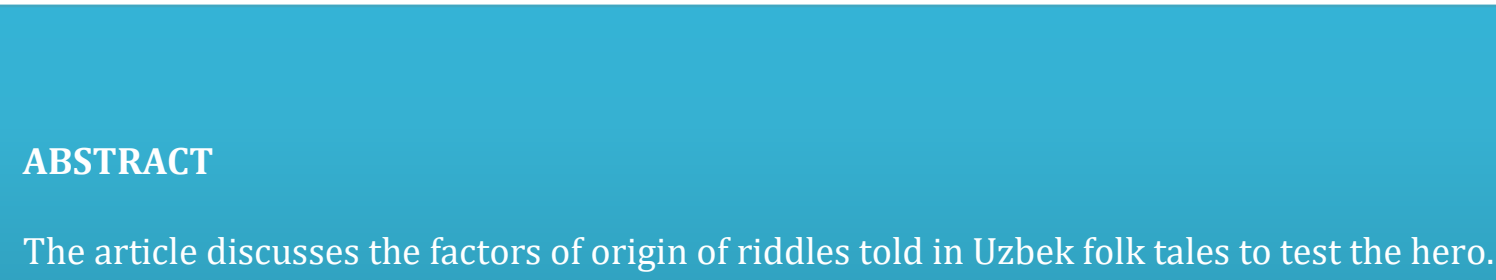

The article discusses the factors of origin of riddles told in Uzbek folk tales to test the hero.

KEYWORDS: - fairy tale, riddle, test motive, ceremony.

\section{INTRODUCTION}

Although riddles are not a separate ritual in Uzbek folklore, there are many motives for testing candidates and selecting a future groom, depending on how they find the answers to the riddles told in the fairy tales as an epic condition. Therefore, according to the Russian scientist SF Baranov, "in ancient times, telling a riddle was considered a means of testing one's intellect. The ancients were interested in coming from a future hunting lodge, raising their hand in the heat of battle, and bringing happiness to their marriage. That is why newlyweds were required to meet certain "test" conditions by special priests before the wedding. Traces of such a test-initiation ceremony, associated with the transition of young people from one age group to another, have been preserved in Russian folklore. In the Russian wedding ceremony, there was a special tradition of "buying and selling" certain objects in the enigmatic discourse between the bride and the groom's friend, not in their own name, but on the basis of a certain characteristic of the thing" [1, p. 131].

The textbook "Russian Folk Oral Poetry", edited by P.G. Bogatirev, also states that in determining the ancient form of the riddle genre, it is necessary to make a comparative analysis of its relatively simple forms, preserved in fairy tales and wedding ceremonies. "Fairy tales and weddings have retained a much simpler form of "unique" expression of thought, i.e. "enigmatic, mysterious" discourse, which is still a genre with a certain artistic structure, rhyme and other poetic features, but simply It was just an example of a "mysterious" speech. Such examples of puzzles, preserved in the epic works and ceremonies, are functionally different from modern riddles, as they are an ancient form of "metaphorical speech": it is usually said to be a riddle to a young man or his friend who is getting married in a fairy tale or ceremony. 
CURRENT RESEARCH JOURNAL OF PHILOLOGICAL SCIENCES 2(11):

53-55, November 2021

DOI: https://doi.org/10.37547/philological-crjps-02-11-13

ISSN 2767-3758

(C)2021 Master Journals

Crossref do

8 Google

Accepted25 $5^{\text {th }}$ November, 2021 \& Published 30th November, 2021

Depending on whether he can find the answer to the riddle, his ingenuity, readiness for life, intelligence, wisdom will be tested. Therefore, it can be assumed that in ancient times a young man who could not find the answer to a riddle was not considered worthy of a bridegroom" [2, p. 215].

In the ancient wedding ceremonies of the riddle genre, "Evidence that it was used as one of the methods of "symbolic testing" is also found in Uzbek folk tales. Recognizing that the genesis of Uzbek folk tales is rooted in ancient marriages, folklore scholar Z. Husainova said, the wide range of such topics has its own life-historical basis. In ancient times, the love of young men and women, their desire to start a family was determined directly by their intellectual level, ingenuity, intelligence, entrepreneurship" was written [3, p. 104].

For example, in the fairy tale "Akhlantoz", the king's daughter, Princess Sahibjamol, promises to the candidates: "Whoever finds the answer to my riddle, I will marry that guy". No candidate can answer the princess's riddles, and only a poor young man can do it. The handsome young man addresses the young man with the following riddle: Uzbek Translation into English Uzoq erda o't kuyur-o,

\section{Uzbek}

Uzoqda o't kuyur-o, Bo'ri ko'zi, oyimqiz.

Sassiq soyda it hurur-o,

Qurbaqalar, oyimqiz.

Chorbog'ingda juft chinor-o,

Ota-onang, oyimqiz.

Eshigingda qo'sh munguz-o,

Ini-og'ang, oyimqiz.

Qora toling butoqsiz,

Qora soching, oyimqiz.

Oqqina qo'zing suyaksiz-o,

Qo'sh anoring, oyimqiz [4, pp. Double pomegranate, charming girl.
Ani toping, Axlantoz.

Sassiq soyda it hurar-o,

Ani toping, Axlantoz.

Chorbog'imda juft chinor-o,

Ani toping, Axlantoz.

Eshigimda qo'sh munguz-o,

Ani toping, Axlantoz.

Qora tolim butoqsiz-o,

Ani toping, Axlantoz.

Oqqina qo'zim suyaksiz-o,

Ani toping, Axlantoz.

Fire burns in the distance,

Find him, Axlantoz.

The dog barks in the ugly stream,

Find him, Axlantoz.

A couple of plane trees in my garden,

Find him, Axlantoz.

Double horn on my door,

Find him, Axlantoz.

Black-tailed deer,

Find him, Axlantoz.

My white lamb is boneless,

Find him, Axlantoz

The fairy-tale protagonist, who came to the princess's puzzle in a bald form, answers:

\section{Translation into English}

Burning fire in the distance,

Wolf's eye, charming girl.

The dog barks in the ugly stream,

Frogs, charming girl.

A couple of plane trees in your garden,

Your parents, charming girl.

Double-edged sword at your door,

Brother and sister.

Black willow without branches,

Black hair, motherfucker. Your white lamb is boneless, 
CURRENT RESEARCH JOURNAL OF PHILOLOGICAL SCIENCES 2(11):

53-55, November 2021

DOI: https://doi.org/10.37547/philological-crjps-02-11-13

ISSN 2767-3758

(C)2021 Master Journals

Crossref dof 81 Google

Accepted $25^{\text {th }}$ November, 2021 \& Published $30^{\text {th }}$ November, 2021

215-217].

In this fairy tale, one of the ancient forms of the wedding ceremony - the custom of testing the groom before the wedding - is reflected. According to tradition, the bride asked the groom (the groom, his close friend and other relatives) certain puzzling questions, and based on the answers to these riddles, the groom's intelligence, resourcefulness, and readiness for family life were tested. The practice of telling riddles was also recognized by Yu.I. Levin in ancient times as one of the customs of the stage of preparation for a wedding. The riddles told during the pre-wedding ceremony or directly during the wedding procession served as a "specific speech" tool to determine which of the bride and groom's social status was higher [5, p. 252].

The wedding ceremony includes a number of rituals that have survived to this day, such as "groom test", "chopping wood", "digging the oven", "ate porridge.", all of which focus on testing the strength, agility and ingenuity of the future groom. These rituals were aimed at physically testing the bridegroom, and in ancient times it was customary to tell riddles in order to determine the height of the bridegroom's intellect. At a certain stage in the development of customs and rituals, when the ritual-magical function of the riddle as a prewedding test ritual lost its force, this ancient tradition was absorbed into the epic plots as a separate motive. Although riddles are not a separate ritual in Uzbek folklore, in many fairy tales there is a motive to test the heroes by telling riddles.
3. Husainova Z. (1989) Enigmatic tales. Essays on Uzbek folklore. Volume 2. - Tashkent: Fan. - p. 104.

4. Gulpari. Uzbek folk art. Namangan fairy tales. Tashkent: Publishing House of Literature and Art, 1967. - pp. 215-217.

5. Levin Yu.I. (1978) Semantic structure of the puzzle. Paremiological collection. - Moscow: Nauka. - p. 252.

6. Ismatullayeva, N. R. Translation of phraseological units in Chinese and Uzbek languages. In Scientific research of the SCO countries: synergy and integration (International conference). Beijing, PRC, June (Vol. 24, pp. 45-50).

7. Khudoyorovich, K. K., Rasuljanovna, I. N., Khalmuratovna, R. Z., \& Eshkobilovna, K. D. (2020). The Issues of Word Choice in Fiction Translation. International Journal of Psychosocial Rehabilitation, 24(04).

\section{REFERENCES}

1. Baranov S.F. (1962) Russian folk poetry. Moscow: - p. 131.

2. Russian folk poetry. - Moscow. 1954. - p. 215. 